\title{
Local Government Capacity Development: A Case Study of a South African District Municipality
}

\author{
Dr. Matuku Mphahlele \\ University of the Witwatersrand \\ Dr. Horacio Zandamela \\ Independent Author
}

Received: Mar. 3, 2021 Accepted: Apr. 9, $2021 \quad$ Online published: Apr. 19, 2021

doi:10.5296/jpag.v11i2.18373～URL: https://doi.org/10.5296/jpag.v11i2.18373

\begin{abstract}
Bojanala Platinum District Municipality (BPDM), in the North West Province is endowed with the extractive economy. The District experiences challenges of capacity development of service delivery structures and programmes. It is in this context that this paper explains how local government responses to challenges of capacity development in the District Municipality. In addition, the paper explores ways in which they can be overcome for enhanced service delivery. The purpose of this study is to examine challenges associated with the use of capacity development structures and programmes in relation to service delivery, and explores how to overcome them. The study examines the structures and programmes, facilitators and inhibitors of skills development and performance initiatives within the context of local government capacity development. This study develops a theoretical framing incorporating scholarship on human capital and performance improvement in the context of local government. This framing is premised on the scholarly evidence that capacity development is an enabler of service delivery, influenced by skills development and municipal performance improvement. The research is a single case qualitative case study approach and employs an interpretative paradigm. The paper employs senior managers in the municipalities as the unit of analysis. The study reveals that there are difficulties associated with skills retention and organisational relations. In conclusion, political abandonment, poor communication and stakeholder engagements contribute to weakened inter-municipal co-operation and inadequate use of resources. The interface between learning and skills development contributes to the body knowledge.
\end{abstract}

Keywords: local government, capacity development, service delivery 


\section{Introduction}

\subsection{The Approach}

This study examines the problem of acquisition of skills and poor service delivery in compliance with the service delivery legislative (Bojanala Platinum District Municipality, 2016). The Bojanala Platinum District Municipality (BPDM) experiences the problem of capacity development programmes not well functioning or meeting the desired outcome in relation to service delivery - stronger capacity. In the South African local government context, key attributes to poor service delivery are inadequate expertise and management capacity (Roux \& Nyamukachi, 2005). In addition to skills deficit in relation to capacity development local municipalities are "poorly funded and institutionally weak" (Guillermo et al., 1999, p.94). Little is known how to overcome service delivery challenges related to lack of skills and instability of the management teams (Bojanala Platinum District Municipality, 2016; Madibeng Local Municipality, 2015). Literature argues that organisations facilitate learning through human capital development (Becker, 1993; Zula \& Chermack, 2007) and performance improvement (Swanson, 1999; Rummler \& Brache, 1988). The study examines not only challenges experienced in the BPDM in relation to capacity development of service delivery structures and programmes but also advances the issues at the interface of human capital and performance improvement theories.

The purpose of this study is to examine the challenges related to the use of capacity development of structures and programmes, and explore how to overcome them for improved service delivery in the Bojanala Platinum District Municipality. This research seeks to answer the following primary question: What are the challenges in effectively utilising capacity development resources and programmes in Bojanala Platinum District local municipalities, and how can they be overcome? Consistent with Badenhorst (2008) this write-up employs the literature review to set out and examine key concepts to develop arguments and counter arguments that inform the methodology. The study employs semi-structured interviews with senior managers familiar with capacity development of structures and programmes in the municipalities. In addition the write-up employs documentary analysis and a descriptive statistics component with the use of questionnaires for confirmatory purpose. Among others, this article employs the literature review to demonstrate a familiarity with a body of knowledge in relation to capacity development. Furthermore, the study shows the path of prior research and how this study links, integrates and summarises what is known in an area; learn from others and stimulate new ideas consistent with Neuman (2006). This article employs the conceptual and theoretical frameworks to frame the study.

Badenhorst (2007) suggests that the conceptual framework not only assists in examining key concepts used in the research but also, identifies the relationship between concepts, outlines analysis of data, and drawing of conclusion. In this article we also underscore the scholastic conversations premised on elements of the conceptual framework, that is, human capital development and performance improvement. The research approach is qualitative in that it provides tools for extensive collection of rich and thick description of data (Merriam, 2002). On the other hand, consistent with Denzin and Lincoln (2011) we employ the naturalistic 
inquiry that explores issues in their natural setting, describes and interprets the phenomenon as perceived by respondents. Data was collected using different methods and sources in the five local municipalities, that is, Kgetlengrivier, Rustenburg, Madibeng, Moses Kotane and Moretele as well as the District over a period of three months in 2016. Thus, the approach enhances credibility and confirmability of the study consistent with (Guba, 1981). The data analysis in this study generates emergent patterns and themes. We employ the Approach section to map-out the context of the study and explore the problem.

\subsubsection{Bojanala District Municipality Context}

The Bojanala Platinum District Municipality (BPDM) consists of five local municipalities and is situated in the north-eastern part in the North West Province.

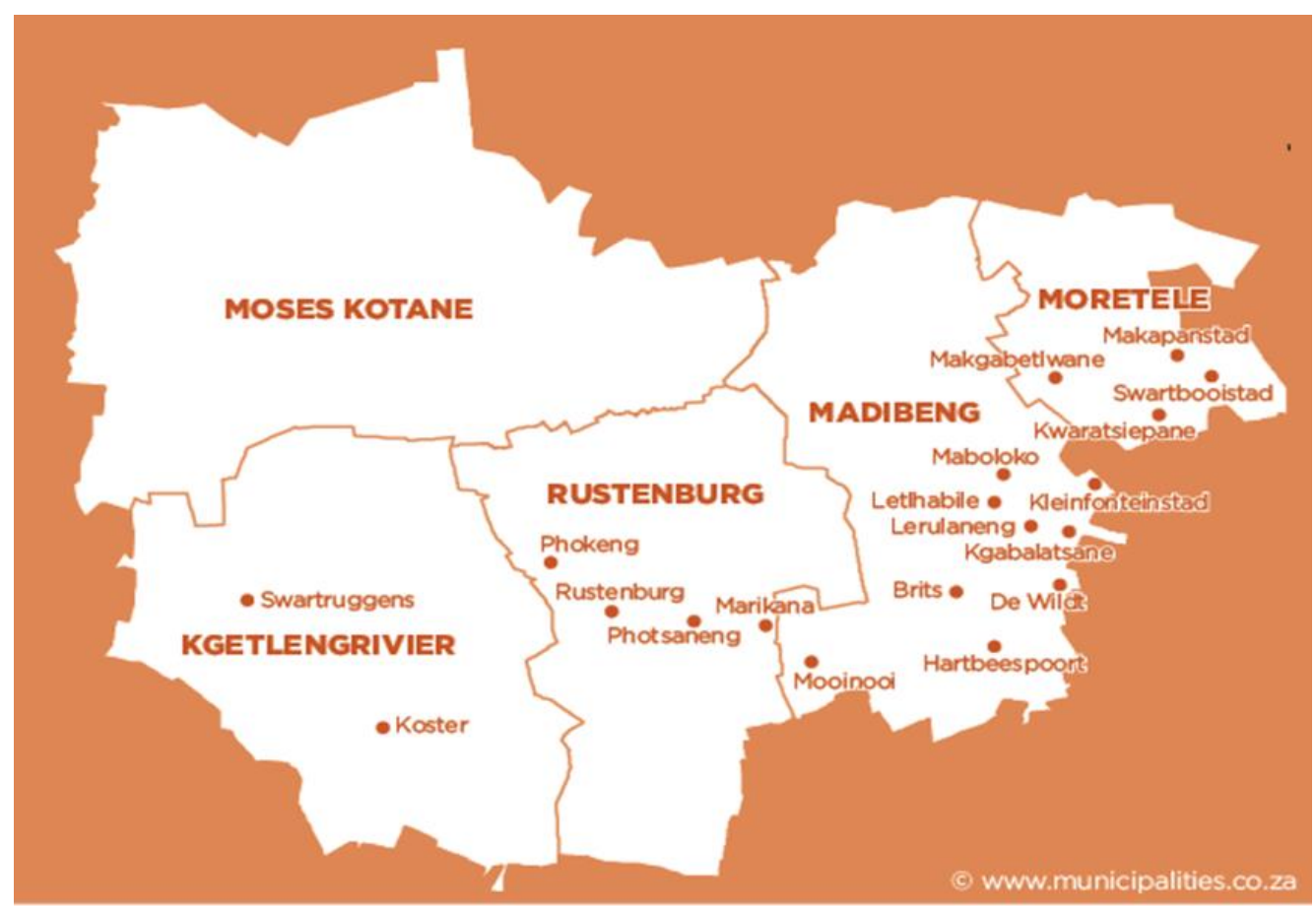

Figure 1. Map of the Bojanala Platinum District Municipality

Source: Local Government Handbook (2016)

Local Government Handbook (2016) in Figure 1 illustrates the five local municipalities in the District are: Kgetlengrivier, Madibeng, Moretele, Moses Kotane and Rustenburg (Bojanala Platinum District Municipality Integrated Development Plan, 2013). The District is located in the 'platinum belt' of South Africa. The 'platinum belt' is renowned for being home to the world's top three multinational platinum producers. The district municipality forms part of the erstwhile Apartheid homeland of Bophuthatswana. Among others the motivation for this paper is we find some peculiar and compelling reasons to conduct this study in relation to the challenges of capacity development of service delivery structures and programmes.

The focus on the legislative context spells out the intentions of the municipal systems and structures in the post-Apartheid era (White Paper on Local Government, 1998). Orientation and description of local government in the context of South Africa underpin the legislative 
orientation in relation to powers and functions (Constitution of the Republic of South Africa Act, 108 of 1996) and development of human resource capacity (Municipal Systems Act, 32 of 2000) in compliance with the Skills Development Act 81 of 1998. Accordingly, consistent with the legislative environment the mandate of a local government is to facilitate provisioning of public services and goods. At a level of municipal district level, orientation and description of BPDM in the context of service delivery underscore capacity development in relation to district-wide planning in the local municipalities as primary functions of the District Councils (Local Government Municipal Structures Act, 117 of 1998). The BPDM is dependent on the mining activities and is directly influenced by the extractive economy. The Constitutional mandate (section 25.4) promotes access to natural mineral resources and transformation of societies (Constitution of South Africa Act, 108 of 1996). However, local municipalities in the mineral-led economy have not succeeded in the alignment of the Integrated Development Plan (IDP) and the Social and Labour Plan (SLP) to develop host communities (Department of Mineral Resources [DMR], 2015). A reflection on the socio-economic issues in the BPDM could give a picture of the extent of effectiveness of implementation of pro-poor developmental policies.

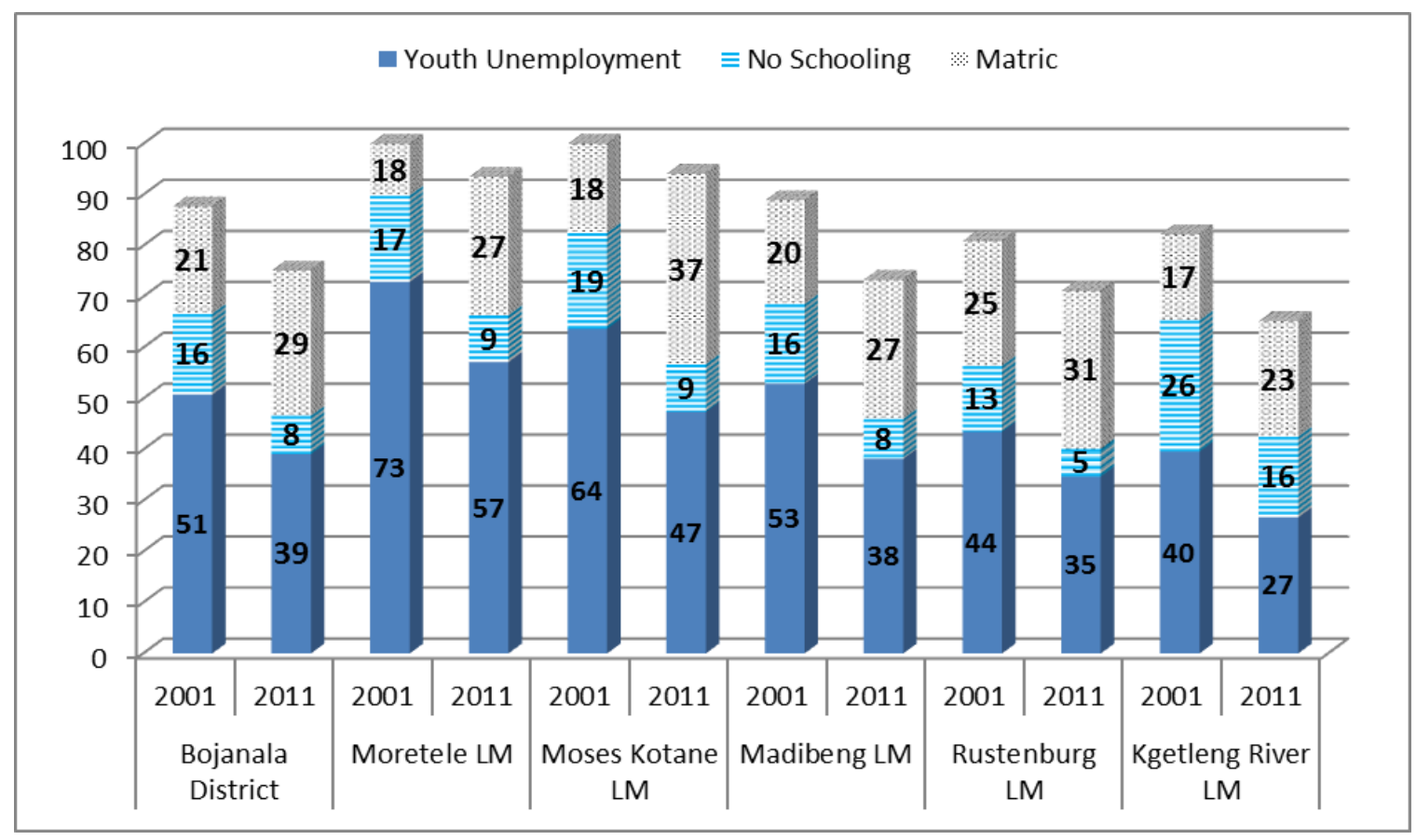

Figure 2. Demographics of Bojanala Local Municipalities (2001-2011)

Source: Statistics South Africa (2013)

The focus on the socio-economic environment contextualises some historical social realities that have a bearing to social problems associated with in-migration and uncontrollable influx of migrant labourers. The BPDM is in a predicament in terms of youth unemployment and the economy embedded in mining activities. The economy of the BPDM is mining-dependent, with $43 \%$ employment in the mining sector and $39 \%$ of the youths unemployed according to the Census 2011 (Statistics South Africa [Stats SA], 2013). In Figure 2, Statistics South Africa (2013) indicates the highest percentage (19\%) improvement of the matriculated youth 


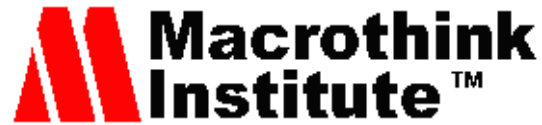

Journal of Public Administration and Governance

ISSN 2161-7104

2021, Vol. 11, No. 2

in the Moses Kotane municipality. The lowest improvement of the matriculated youth is in Kgetlengrivier Local Municipality at $6 \%$. The extent of poverty and unemployment differs among the local municipalities with Moretele at 57\% level of unemployment compared to an average of $39 \%$ across all local municipalities in Bojanala. South Africa conducts national Census every ten years and the most recent were released in 2013.

Table 1. Bojanala Platinum District Municipality population density

\begin{tabular}{|c|c|c|c|c|c|c|c|c|c|}
\hline \multirow[t]{2}{*}{ Municipality } & \multirow{2}{*}{$\begin{array}{c}\text { Population } \\
2011 \\
\end{array}$} & \multirow{2}{*}{$\begin{array}{c}\begin{array}{c}\text { Population } \\
(\%)\end{array} \\
2011 \\
\end{array}$} & \multirow{2}{*}{$\begin{array}{c}\text { Population } \\
2016 \\
\end{array}$} & \multirow{2}{*}{$\begin{array}{c}\begin{array}{c}\text { Population } \\
(\%)\end{array} \\
2016 \\
\end{array}$} & \multirow{2}{*}{$\begin{array}{c}\begin{array}{c}\text { Population } \\
\text { increase (\%) }\end{array} \\
2011-2016 \\
\end{array}$} & \multirow{2}{*}{\multicolumn{2}{|c|}{ Land Area $\left(\mathrm{km}^{2}\right)$}} & \multicolumn{2}{|c|}{$\begin{array}{l}\text { Population density } \\
(\text { Population/km²) }\end{array}$} \\
\hline & & & & & & & & 2011 & 2016 \\
\hline $\begin{array}{l}\text { Bojanala } \\
\text { District }\end{array}$ & $1,507,506$ & $100 \%$ & $1,657,060$ & $100 \%$ & $9.9 \%$ & 18,370 & $100 \%$ & 82 & 90 \\
\hline Moretele & 186,947 & $12 \%$ & 189,900 & $11 \%$ & $1.6 \%$ & 3,847 & $21 \%$ & 49 & 49 \\
\hline Moses Kotane & 242,554 & $16 \%$ & 243,600 & $15 \%$ & $0.4 \%$ & 5,731 & $31 \%$ & 42 & 43 \\
\hline Madibeng & 477,381 & $32 \%$ & 537,500 & $32 \%$ & $12.6 \%$ & 1,382 & $8 \%$ & 345 & 389 \\
\hline Rustenburg & 549,575 & $36 \%$ & 626,500 & $38 \%$ & $14.0 \%$ & 3,430 & $19 \%$ & 160 & 183 \\
\hline Kgetlengrivier & 51,049 & $3 \%$ & 59,560 & $4 \%$ & $16.7 \%$ & 3981 & $22 \%$ & 13 & 15 \\
\hline
\end{tabular}

Source: Statistics South Africa $(2013 ; 2016)$

The Bojanala Platinum District Municipality is a typical rural municipality with a sparsely spread population over vast areas. Presentation of the population density in Table 1 (Statistics South Africa, 2013; 2016) indicates that Madibeng has the highest population density $(58 \%)$ or 389 people per square kilometre, whereas Kgetlengrivier local municipality has the least at 2\% (Statistics South Africa, 2016). In the five-year period 2011-2016 the population in the BPDM increased by about $10 \%$. High population density in the Rustenburg and Madibeng local municipalities could overstretch the municipal budget and exacerbate difficulties in relation to access to municipal services, for instance, water, energy and sanitation facilities. Thus, encourage social ills, unemployment, social and economic exclusion of the youth.

It is our belief that, although it is not the objective of the paper to examine the intersection of the local government and mining companies, however, understanding of the legislative space common to both local government and mining environments assists in understanding the underlying factors that impact on capacity development of service delivery structures and programmes. The BPDM experiences difficulties in the acquisition of skills to comply with the service delivery legislative (Bojanala Platinum District Municipality, 2016). The National Treasury (2011) describes rural local municipalities to be characterised by sparsely populated areas that depend on natural resources and to some extent depend on migratory labour. According to the Mineral and Petroleum Resources Development Act 28 of 2002 (MPRDA) mining companies have to establish collaborative service delivery partnerships with host local municipalities. The Department of Mineral Resources (2015) reveals that "nationally only $36 \%$ of mining right holders have met their set target on mine community development" (p.30). This low level of commitment to meeting the required target could be indicative of 
little or no relationship between mining companies and local municipalities.

The Commonwealth Local Government Forum (2012) and Local Government Turnaround Strategy Report (Department of Co-operative Governance and Traditional Authorities, 2009) state that basic service delivery is confronted by the challenges of human resource capacity, funding capacity constraints and credible public participation. These challenges have led to this paper to examine enablers and disablers inadequately explored in the contemporary academic discourse in relation to the use of capacity development of service delivery structures and programmes. Examination of the space of capacity development of service delivery structures and programmes and exploration of challenges peculiar to BPDM is against the backdrop of inconsistent and contradictory literature perspectives. In addition, we explore measures to overcome capacity development challenges in relation to service delivery in the Bojanala Platinum District Municipality.

\subsubsection{Capacity Development Enablers and Disablers in the Context Local Government}

This paper delves into the contemporary discourse on capacity development, and service delivery enablers and disablers in the context of developing and developed countries. We further note that capacity cuts across not only the public but also the private sector and communities. This prompts the primary question: What are the challenges of capacity development of service delivery structures and programmes in Bojanala Platinum District local municipalities, and how can they be overcome? The write-up examines employee skills development and municipal performance. Skills development entails issues generated from the human capital framework. Furthermore, we delve into capacity development and human resource development as enablers and disablers of capacity development. This prompts the question "what are structures and programmes for enhancing capacity development, and what do their experiences show?" Capacity development is defined as a "locally driven process of learning by leaders, coalitions and other agents of change that brings about changes, in socio-political policy-related and organisational factors to enhance local ownership, effectiveness and efficiency of efforts to achieve a developmental goal" (Otto et al., 2009, p.9). The Organisation for Economic Co-operation and Development (2008) adds that "capacity development is a process whereby people, organisations and society unleash, strengthen, adapt and maintain capacity over time" (p.244). Thus, human resource development (HRD) as primary tool and enabler to advance effective capacity development cuts across all sectors, increases knowledge, skills and capacity (Harbison \& Myers, 1964). The capacity to facilitate achievement of locally-driven and locally-owned developmental goals strengthens in an environment conducive for optimisation of service delivery.

In the South African local government context, service delivery describes the distribution of basic resources such as water, electricity, sanitation, infrastructure, land and housing to the satisfaction of communities (Akinboade et al., 2014; Fox \& Meyer, 1995; Ndebele \& Lavhelani, 2017; Nealer, 2014). In the context of the legislation service delivery is the provision of sustainable services by the municipality to communities (Constitution of South Africa Act, 108 of 1996). Public service delivery is necessary to ensure an acceptable and reasonable quality of life and, if not provided, would endanger public health, safety, or the 
environment (Local Government Municipal Systems Act, 32 of 2000). Maintenance of capacity over time could be subjected to performance-oriented sustainable services leaned towards pursuance of public interests.

Optimisation of municipal performance could be subjected to pursuance of self-interest (Fairhurst, 2007) or pursuance of public interests (Huang \& Feeney, 2016). This prompts the question "What are facilitators and inhibitors of skills development initiatives in relation to implementation of service delivery programmes?". Actions and omissions associated with political elitism negatively impact on service delivery, the literature suggests. Political elitism characterised by pursuance of narrow personal interests and resultant workplace employee stress typifies local government environment (Hodder, 2009; Ngwenya \& Botha, 2014). A stressful workplace impacts on service delivery and has a bearing on how employees perceive human resources management (Dzansi et al., 2016). Understanding of the afore-mentioned narratives on human capital and municipal performance stimulates the appetite to examine socio-economic elements in a rural municipal setting typical of the BPDM. Rurality of local government municipal settings is characterised by the 'resource curse' and unsustainable remittance system.

Earlier scholarly debates report on aspects related to political elitism, rural-urban imbalance and the economy of the remittance system, and how to some extent they impact on capacity development of service delivery initiatives in both the internal and external environments of local municipalities. The nature of the nexus of rural-urban setting and locality of the municipality impacts on functionality of municipal governance in relation to facilitation of service delivery. Consistent with National Treasury (2011) we note that rural local municipalities also depend on natural resources, and generally characterised with unfavourable bearings on service delivery, that is, a 'curse' against enhancement of service delivery initiatives. Typical of the 'resource curse', municipalities and communities located in an extractive economy dominated environment tend to be under-developed despite provision of labour from the host communities for the multi-national mining companies. Lack of capacity fuels the resource curse that enriches political elites at the expense of ordinary citizens (Busse \& Gröning, 2013; Hoyos, 2019). Thus, to some extent social and economic development of rural municipalities are intrinsically intertwined with the migratory labour setting. The concept of rural-urban nexus is complex due to the nature of migration referred to as translocal livelihood (Lohnert \& Steinbrink, 2005). To cite an example, Steinbrink (2010) attributes the flow of money, cultural identity and livelihoods to complexities of the rural-urban imbalance or inequality ascribed to the persistent mobile community settings. The historic traditional 'walk to the mine' of African males in Southern Africa, gives rise to remittance arrangement to support households back home (Adaawen \& Owusu, 2013; Amoako \& Apusigah, 2013; Lohnert \& Steinbrink, 2005; Mayer \& Mayer, 1971; Sana \& Massey, 2005; Stark, 1991; Stark \& Lucas, 1988; Steinbrink, 2010). The remittance arrangement common in a migratory labour setting by its nature may not always be able to improve earned income of mineworkers, and may aggravate issues with fathers back home squandering the hard-earned monies sent by their sons (Abdul-Korah, 2011; Kwankye; 2012; Serbeh et al., 2015). 
Lastly, the nature of cooperation between local municipalities and cooperation of local municipalities in partnership with the private sector has a bearing on impediment or facilitation of capacity development of service delivery structures and programmes. Inter-municipal co-operation increases production, and preserves local autonomy without impacting negatively on average municipalities (Allers \& de Greef, 2018; Soukopová \& Vaceková, 2018). However, to the contrary Blaeschke and Hang (2018) argue that although the inter-municipal co-operation increases production, it nonetheless complicates co-ordination of stakeholder interests due to the spread of accountability of a wider spectrum and subsequently lowers the degree of technical efficiency. Contrary to the perspectives on inter-municipal co-operation in Allers and de Greef (2018), Soukopová and Vaceková (2018) the satisfactory delivery of basic resources in conjunction with the private sector (public-private partnership) not only promotes optimisation of technical and management capacity, but also improves performance of services of municipalities (Germà \& Gradus, 2018; Shava \& Maramura, 2016).

To sum it up, despite the political changes following the erstwhile Apartheid System, host local municipalities in rural mining areas are still characterised by the discriminatory labour system, for instance the migrant labour system characterised by cheap labour practices, consistent with Wolpe (1972). The literature argues that a persistent selective 'urban bias' of developmental programmes leads to exclusion of rural societies from access to basic services, in the main, due to the unstable and mobile migrant societies (Lipton, 1977). This write-up notes that coalition agents of change in the enhancement of service delivery are impacted upon by the socio-political and human resource development environments. Thus, organisational skills development and performance improvement initiatives underpin the thematic orientation of this paper in relation to enablers and disablers of local government capacity development. The influence of political elites in the appointment of under-qualified staff and employees steeped in personal value interests are disablers of capacity development of service delivery structures and programmes. Actions and omissions associated with political elitism negatively impact on the human resource management practices characterised by pursuance of narrow personal interests (Hodder, 2009). Political interference as a disabler lowers the morale, heightens stress among workers and has a bearing on employee performance in relation to service delivery (Dzansi et al., 2016; Ngwenya \& Botha, 2014). The rural nature and socio-economic setting of a municipality characterised by sparsely populated areas, outflow of money and unsustainable livelihoods have an unfavourable bearing on capacity to optimise service delivery. The remittance system encourages 'fiscus flight' or narrowing of the local tax base due to lack of housing ownership or investment. Thus, payment of tax and municipal rates necessary for capacity development of the society dries up. Challenges of co-ordination of stakeholder interests in an inter-municipal cooperation due to the uneven spread of accountability among local municipalities can weaken initiatives to enhance capacity development and service delivery. However, the use of a collaborative municipal owned cooperation with the private sector could encourage the transfer of skills and heighten competitive public-private partnership that facilitates capacity development. 


\section{Macrothink}

Recent literature hones in on inter-municipal co-operation (Allers \& de Greef, 2018; Soukopová \& Vaceková, 2018), employee pursuance of public interest (Huang \& Feeney, 2016) and political elitism (Busse \& Gröning, 2013; Hoyos, 2019). On the other hand earlier studies delve on rural-urban nexus (Lohnert \& Steinbrink, 2005; Steinbrink, 2010) and remittance system (Adaawen \& Owusu, 2013; Amoako \& Apusigah, 2013; Lohnert \& Steinbrink, 2005; Mayer \& Mayer, 1971; Sana \& Massey, 2005; Stark, 1991). Literature advances similar, dissimilar and contrasting arguments in relation to the impediments and facilitators of capacity development from different contexts. Little is known how capacity development of service delivery structures and programmes can be overcome at a local government level.

\subsection{Framing of the Research Study}

The study examines old theoretical relationships and explores new theories in order to get better understanding of the studied phenomenon. A conceptual framework "helps to model relationships between theories; reducing theoretical data into statements or models; explicating theories that influence the research; creating theoretical links between extant research, current theories, research design, interpretations of findings and conceptual conclusions" (Leshem \& Trafford, 2007, p.101). Badenhorst (2007) points out that the conceptual framework assists in examining the key concepts used in the research, identifies the relationships between concepts, and provides the basic outline for analysing the data and drawing conclusion. The conceptual framework as the outcome of the literature review not only underpins the knowledge gap generated from understanding the research problem but also, contributes to explanatory theoretical framework for interpreting the findings. 


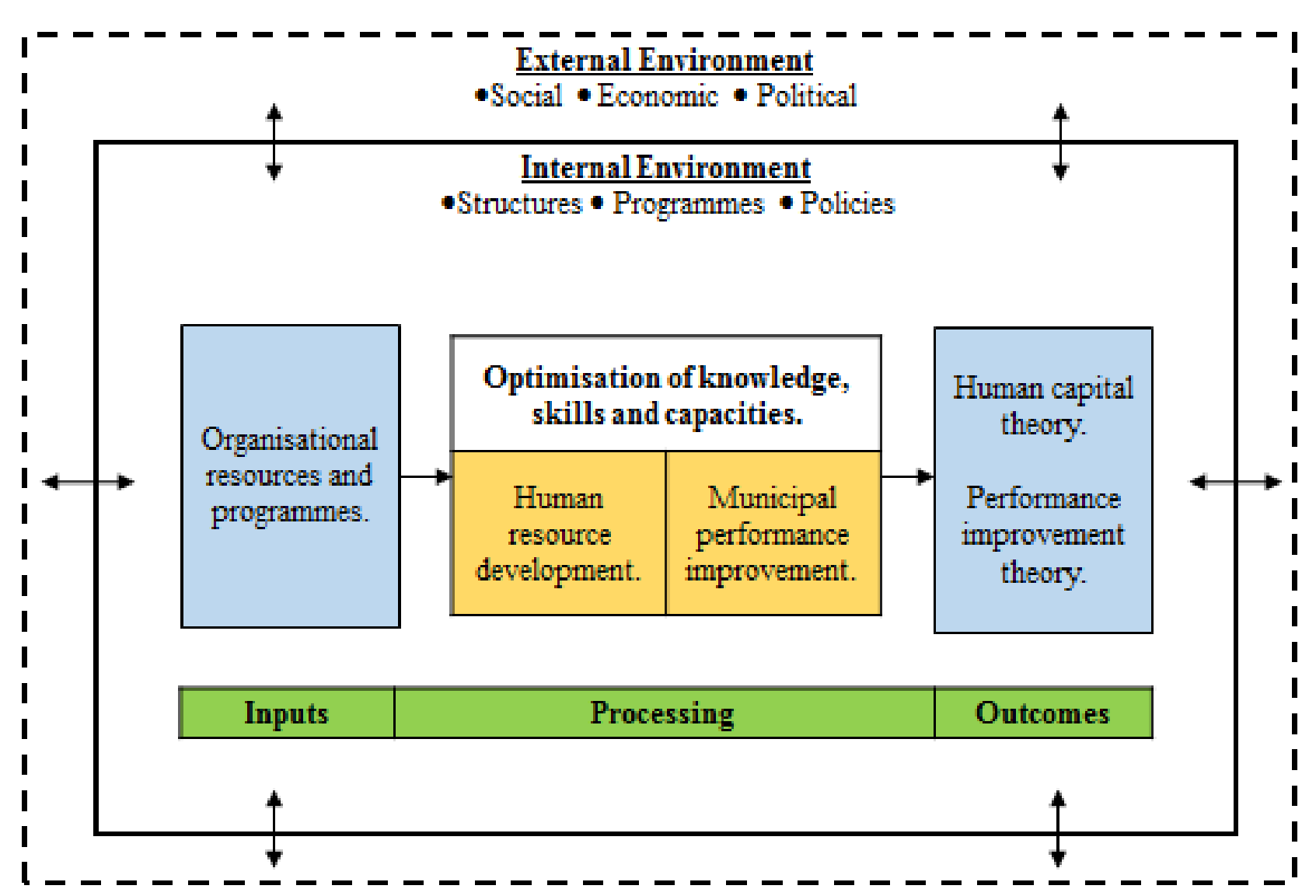

Figure 3. Representation of the Theoretical Framework

Source: Authors (2019).

Representation of the theoretical framework in Figure 3 illustrates a synopsis of the elements peculiar and distinct in the advancement of capacity development premised on the literature review. Maximisation of the utilisation of organisational resources and processes is suggested as an important output of the human capital and performance improvement theories. However, prior to achievement of the developmental outcomes, inputs are processed within the internal environment informed by organisational structures, programmes and policies. The non-static and non-linear elements of the internal environment and external socio-economic and political environments interact and inter-twine in a peculiar manner. The integration of these elements heightens prospects for creation of a learning environment conducive for human resource development and municipal performance improvement.

Human capital and performance improvement theories are applicable to this study. The human capital theory (HCT) emphasises investment in training (Snell \& Dean, 1992); informal workplace education (Schultz, 1981) and on-the-job education (Corazzini, 1967; Mincer, 1974). However, to the contrary, Ubels et al. (2010) argue that the mere presence of education and training structures does not warrant successful outcomes or functional capacity development. Performance improvement theory is premised on the grounds that performance could be developed through skills development (Gilbert, 1978; Rummler \& Brache, 1988). 


\section{Macrothink}

Sanderson (2001) argues that a non-static systemic infrastructure enhances a culture of performance. Thus, the optimisation of performance is closely associated with a supportive decision-making systemic infrastructure. Notwithstanding, the creation of a supportive environment corroborated in Denison (1967), and to the contrary Moynihan (2010), Gagne and Deci (2005) advance the argument that rewards result in inadequate performance and decreased productivity.

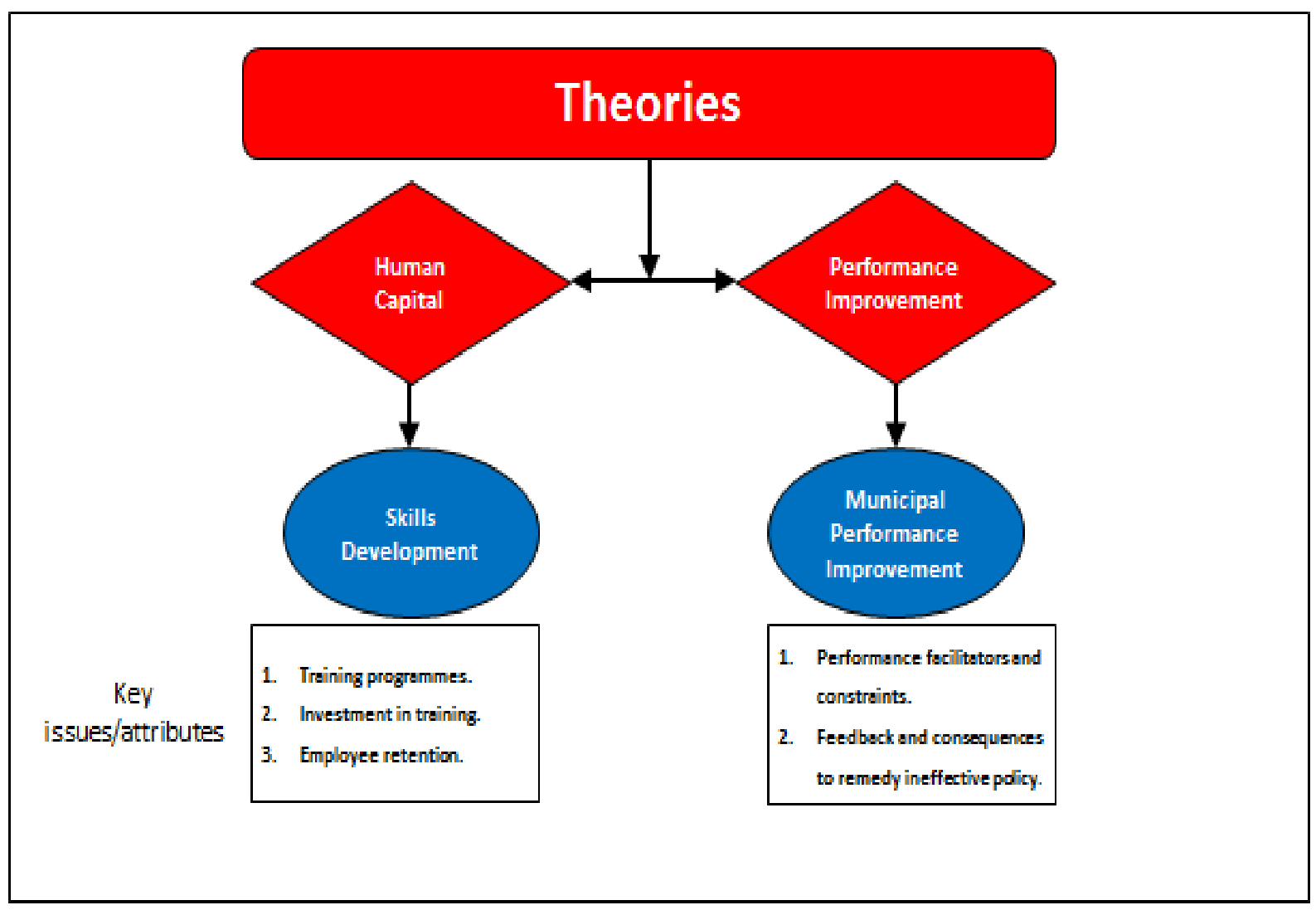

Figure 4. Capacity development Conceptual Framework

Source: Authors (2019)

The write-up illustrates with a graphical representation, Figure 4, the conceptual framework of the research study and the emergent issues generated from understanding of the relevant fore-going scholarly debates. The interdependence of skills development and municipal performance aspects in relation capacity development of service delivery structures and programmes underpins skills development as the leading enabler. Thus, the conceptual framework illustrates the concept of skills development and demonstrates how the assertion that investment in structures and programmes could facilitate capacity development. Municipal performance facilitates improvement of services influenced by the peculiar and distinct aspects, that is, performance facilitators, fruitful feedback and responsive consequence management to redress ineffective implementation of pro-poor developmental goals and policies. 
The foregoing examination of the research problem and framing of the study underpins distinctive elements to understanding of capacity development within the interspace of skills development, and performance improvement in the context of a South African local government tier of governance. Thus, provokes the question of what methodology is employed in the study.

\section{Method}

The research methodology employs a purposely selected sample of respondents. The Bojanala Platinum District Municipality is the case and senior managers in all municipalities constitute the unit of analysis. In-depth face-to-face interviews were conducted among 30 senior managers in the office of the Integrated Developmental Plan (IDP), Local Economic Department (LED), Chief Financial Officer (CFO), Human Resources (HR) and the Municipal Manager. The 30 municipal officials were purposively sampled consistent with their knowledge and roles in relation to capacity development in their respective departments or units. Their rich knowledge of the phenomenon of capacity development, and meaning thereof provides a deep understanding in the examination and interpretation of findings of this study. Accordingly, interpretive paradigm of choice for this study by its nature serves as a vehicle and enabler in the interpretation of managers' understanding of multiple beliefs or experiences on municipal capacity development.

The second phase of the study employs non-probability judgment sampling of 52 participants at junior and middle management. Originally the study planned to collect data from 55 respondents. Two questionnaires were spoilt and one was not returned. We employ complementary descriptive statistics component for confirmatory purpose consistent with the argument by Morse (1991). Furthermore, justification for the descriptive statistics component is in alignment with the sequential triangulation of the qualitative method whereby in-depth interviews precede descriptive statistics consistent with Field and Morse (1985). The Likert Scale credited to Likert (1932) is used to measure the intensity of the attitude of respondents generated from questionnaires on the strength of "Agree", "Strongly Agree", "Disagree" and "Strongly Disagree" premised on the non-numerical ordinal scale. The study also hones in on data presentation and discussions, and further delves into analysis of findings and conclusion.

\section{Results and Discussions}

\subsection{Data Representation}

Data presentation underscores general subjective perspectives and patterns premised on the research questions related to challenges experienced in acquiring resources, challenges related to improvement of service delivery programmes and explanation of why skills development programmes experience difficulties in relation to development of service delivery. In general respondents perceive budget constraints, political interference, municipal grading, and employee retention as key disablers or impediments of skills development. Respondents also advance the views that disjointed employee performance assessment, uncontrolled labour in-migration, poor managerial skills, lack of community participation, inadequate inter-departmental and inter-governmental relations are aspects that inhibit 
municipal performance improvement. To cite an example of the key responses associated with in-depth interviews rural local municipalities are more at a disadvantage compared to the urban local municipalities in relation to budget allocation as suggested by Respondent 09 (personal communication, June 30, 2016). The study points out a distinctive response that corroborates the literature, that is, political interference creates a "poisonous environment" (Respondent 09, personal communication, June 15, 2016). Respondents strongly raised opinions suggestive of political principals disrespectful of their authoritative managerial positions and roles. To cite an example, some councillors would hurl insults and instructions like "listen here I am the boss and I instruct you to appoint so and so" (Respondent 10, personal communication, July 11, 2016). This conduct is indicative of a poor working relationship between senior administrators and the political principals. The pattern of perceptions and experiences in relation to organisational performance are indicative of a differential budget allocation premised on the rural geographic setting that impedes collection of revenue, skills retention and provision of quality public services which subsequently instigate community protests, Respondent 17 (personal communication, July 12, 2016), Respondents 11, 12 and 15 (personal communication, July 06, 2016) suggest.

Questionnaire data presentation and discussions reveal the need to improve work related skills. In relation to impediments of organisational performance respondents strongly support improvement of inter-governmental relations. Documentary analysis presents the municipal fiscal allocation from $2012 / 13$ to 2014/15. The fiscal allocation underscores that the Madibeng and Rustenburg local municipalities received the biggest share of the cake of R1.3b and R3b respectively (Local Government Handbook, 2016). Despite the rural nature and high poverty level of Kgetlengrivier, the municipality underspent R41.6m. Furthermore, the District spent R141m on 381 employees, whereas Moses Kotane with double the employees of the District spent R7m less than the District on employees. The Auditor's Report (2018) finds shortcomings in the management and administration in relation to leadership, financial and performance management. The Bojanala District Municipality incurred unauthorised, irregular, fruitless and wasteful expenditure in breach of the Municipal Finance Management Act 56 of 2003, Section 32(2)(a)(ii). In addition, the Auditor's Report (2018) advances concerns about awarding of services to municipal employees year after year in contravention of section 38(1) of the Supply Chain Management regulation. The Report also highlights lack of adherence to the legislative tools in relation to service delivery including lack of consequence management. The District did not have finalised audits in the financial year 2014-2015. Moreover, the District experienced a disclaimer audit opinion with findings in both 2015-2016 and 2016-2017 financial years. Only Kgetlengrivier local municipality experienced unqualified audit opinion with findings in the 2016-2017 financial year. Notwithstanding the challenges of the District, according to the local government legislation the District is the custodian of capacity development and has a legislative mandate to support the five local municipalities. The study also presents an analysis and discussions of main findings.

\subsection{Analysis and Discussion of the Main Findings Reveals Four Subthemes}

1. Organisational relations synergy; 
2. Organisational resilience;

3. Capacity building empowerment; and

4. Enhancement of service delivery

Organisational relations synergy reveals that capacity development initiatives of service delivery structures and programmes are under-resourced and disjointed. Consequently, the respective projects are poorly co-ordinated and inadequately implemented. Among others, inadequate communication between the politicians and senior management puts some strain on the initiation and implementation of capacity development structures and programmes. Poor departmental and inter-departmental relations and lack of transparent recruitment processes impact negatively on administrative synergy. Inadequate administrative synergy, lack of organisational resilience and visionary leadership stand out as responses to the interview question: Why are capacity development structures ineffective in the enhancement of service delivery programmes? The volatile socio-political milieu and lack of functional inter-departmental administrative synergy stand out as impediments or disablers of capacity development in relation to organisational resilience. Among others, scarcity of a political will, prevalence of political elitism and the loss of skills to national and provincial government spheres as posited by Respondent 01 (personal communication, May 20, 2016) and Respondent 02 (personal communication, July 12, 2016) are suggestive of difficulties that creep into organisational resilience in the local municipalities. Lack of capacity building and empowerment is suggestive of poor management and inadequate administrative synergy. Findings depict the general pattern of insights peculiar to enhancement of capacity development. Indications of the laissez-faire organisational environment (Respondent 09, personal communication, June 30, 2916) could be typical of an environment unable to fulfil its capacity development constitutional mandate. Worldviews among the respondents are reflective of a complex multi-stakeholder political constituency riddled with challenges of visionary leadership, limited sharing of common purpose and commitment to societal needs.

It is against the complex socio-political setting of local government that Total Quality Management (TQM) model by Deming (1982) inspires further examination of the management of quality of supporting structures, programmes and systems in relation to capacity development. According to Deming (1982) the TQM model advocates for localisation of issues that are grounded in well-established research structures and systems. In addition, findings in this paper advance distinct elements related to capacity development that prompted the study to explore and examine knowledge management, mentoring and change management. An overwhelming worldview that promotes communication of knowledge from senior to lower levels of management is corroborated by Kickert (2014), McAdam and McCreedy (1999); Van der Voet et al. (2016). Functional communication promotes organisational collaborative participation necessary for strengthening administrative synergy. Although mentoring could develop and sustain organisational relations consistent with Gordon (2000), however due to the distinct elements associated with political interference at workplace, there could be some impediments to creation of a workplace environment conducive for implementation of mentoring relationships and programmes. Disablers linked 


\section{Macrothink}

to old practices and rigid organisational culture blemished with undesirable habits could be difficult to 'unfreeze' or change due to the inherent comfort zone (Lewin, 1947). Thus, the need to overcome the deterrents to organisational change located in the comfort zone. The paradigm shift in this regard depends on the ability to initiate capacity development plans guided by visionary and strategic leadership consistent with Kotter (1996). Successful integration of functional capacity development of service delivery structures and programmes could sustain the vision to continuously eliminate 'silos' managerial practices in view of the prevailing laissez faire organisational practices.

Most importantly, recognition of some limitations of this study suggests possible avenues for further research without compromising the value of the findings. First, this naturalistic inquiry employs a limited sample of 31 respondents and could raise concerns over transferability of findings. Second, the research focuses on five local municipalities which can be viewed as unique in relation to the organisational culture and may differ considerably from other local municipalities. Interviews were held just a few days before the local government elections in South Africa, on 3 August 2016. In the context of local government elections by its nature the timing of interviews coincided with a highly politicised period of uncertainty, as most of the senior managers have their positions linked to the five-yearly municipal elections

\subsection{Conclusion: Towards Skills Retention and Building of Organisational Relations}

An analysis of findings reveals the two emergent themes, that is, skills retention and organisational relations that corroborate with issues in the literature review. In the context of this study capacity development is the maximisation of operational enablers, political integrity and socio-economic diversity in order to implement transformational programmes through good governance and public accountability. Premised on the intricacy of inadequate operational structures and programmes, maximisation of enablers of capacity development through built-in organisational administrative synergy and socio-political integrity could facilitate capacity development of service delivery structures and programmes. 


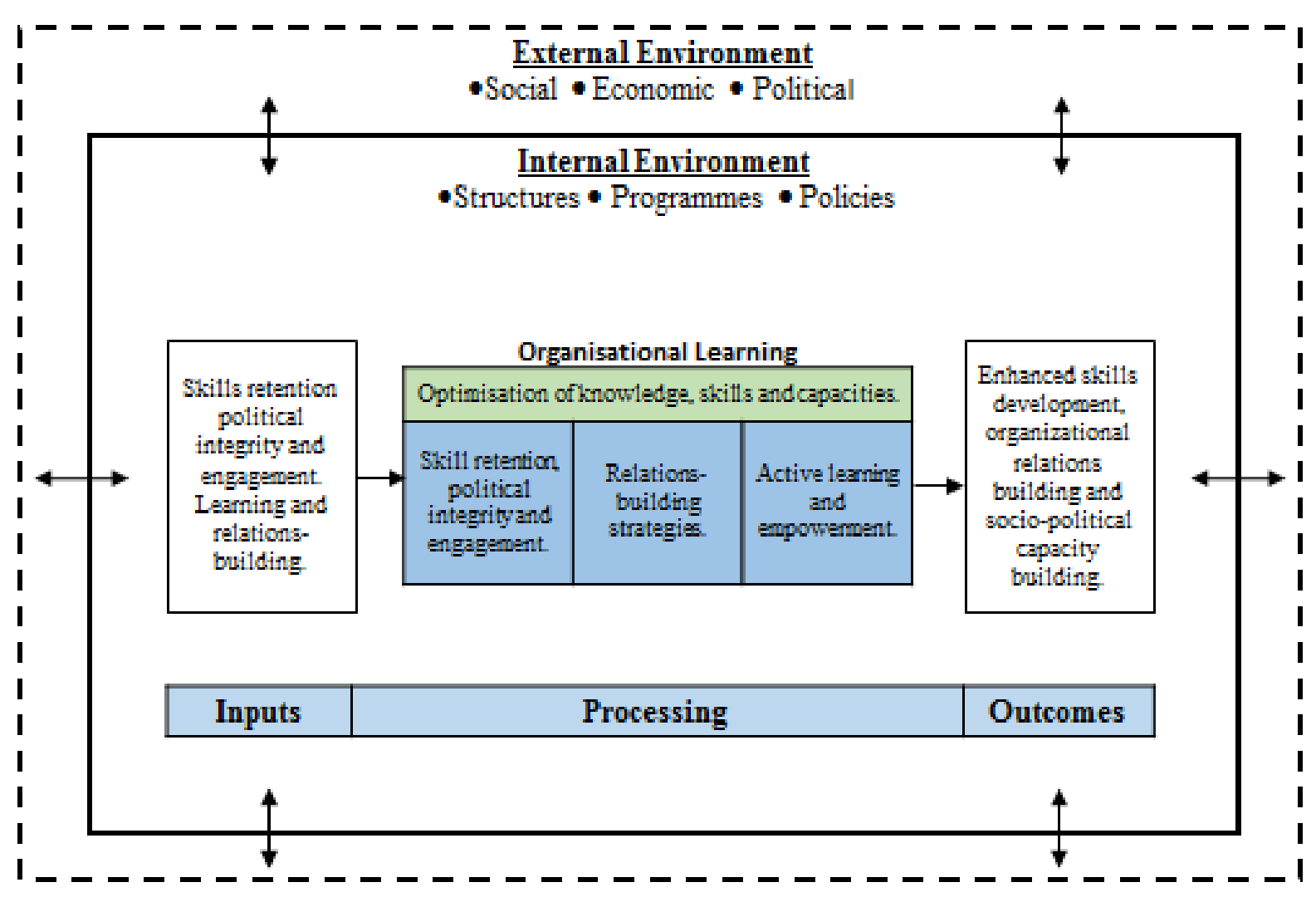

Figure 5. Capacity development oriented Learning Theory

Source: Authors (2019)

Contribution to the study is generated through employment of the theoretical perspectives and conceptual orientations. This study presents a theory premised on understanding of the richly explained phenomenon of capacity development. Thus, in Figure 5 the study constructs a performance-oriented learning theory that introduces a new trajectory to advance capacity development. It is the firm argument of this study that on the grounds of impediments to capacity development; inter-departmental and inter-municipal co-operation are effective twosome capacity development facilitators.

This study reveals that accountability, human and financial resources are in essence major inputs in the creation of a solid foundation for capacity development. The non-linear process of optimisation of outcomes of capacity development commences with the integration of an input-oriented public accountability. It is against the context of findings that this study employs a combination of mentoring, knowledge and change management strategies, that is, indicative of functional gears essential to efficiently generate outputs in the form of skills retention and organisational relations. Findings of this study also reveal that socio-political resilience and administrative synergy impact on achievement of local government capacity development goals. Most significantly, effective outcomes that seek to meet the developmental goals may be subjected to continuous monitoring, collaborative evaluation 
and revised accordingly with representative stakeholders.

The paper suggests the following future studies: Organisational capacity development and strategic oversight in the context of local government; strategic reorientation of the performance management system in the local government sphere; collaborative partnerships and functional roles of mining companies in local government economic development programmes.

\section{Acknowledgments}

The authors express sincere gratitude to municipal managers, senior managers and employees of the Bojanala Platinum District Municipality and the local municipalities that participated in this study. The project did not get a financial support. Matuku Mphahlele extends deepest appreciation to his supervisor Dr. Horacio Zandamela on preparation of this paper as a variant of his $\mathrm{PhD}$ studies.

\section{References}

Abdul-Korah, G. B. (2011). Now if you have only sons you are dead: Migration, Gender and Family Economy in Twentieth Century Northwestern Ghana. Journal of Asian and African Studies, 18(4), 390-403. https://doi.org/10.1177/0021909611400016

Adaawen, S. A., \& Owusu, B. (2013). North-South Migration and Remittances in Ghana. African Review of Economics and Finance, 5(1), 29-45. https://www.ajol.info/index.php/aref/issue/view/11183

Akinboade, O. A., Mokwena, M. P., \& Kinfack, E. C. (2014). Protesting for Improved Public Service Delivery in South Africa's Sedibeng. District Social Indicators Research, 119(1), 1-23. https://doi.org/10.1007/s11205-013-0377-9

Allers, M. A., \& de Greef, J. A. (2018). Inter-municipal co-operation, public spending and service levels. Local Government Studies, 44(1), 127-150. https://doi.org/10.1080/03003930 .2017. 1380630

Amoako, E.E., \& Apusigah, A.A. (2013). Gender, Migration and Remittances in Ghana An Overview. Ghana Journal of Development Studies, $10(1 \quad \& \quad 2), \quad 15-43$. https://doi.org/10.4314/gjds. v10I1\&2.2

Auditor-General. (2018). Consolidated general report on the audit outcomes of Local Government 2016-2017. Government Printers.

Badenhorst, C. (2008). Dissertation writing: A research journey. Van Schaik Publishers

Badenhorst, C. (2007). Research Writing: Breaking the Barriers. Van Schaik Publishers

Becker, G. S. (1993). Human Capital: A theoretical: A theoretical and empirical analysis with special reference to education. The University of Chicago Press.

Blaeschke, F., \& Haug, P. (2018). Does inter-municipal cooperation increase efficiency? A conditional meta-frontier approach for the Hessian wastewater sector. Local Government 
Studies, 44(1), 151-171. https://doi.org/10.1080/03003930.2017.1395741

Bojanala Platinum District Municipality. (2016). Bojanala Annual Report 2014-2015. http://www.bojanala.gov.za/janala.boja/wp-content/uploads /2016/05 / BPDM-AnnualReport-2014-15.pdf

Busse, M., \& Gröning, S. (2013). The resource curse revisited: Governance and Natural Resources. Public Choice, 154, 1-20. https://doi.org/10.1007/s11127-011-9804-0

Commonwealth Local Government Forum. (2012). Local Governments in Southern Africa: An Analytical Study of Decentralization, Financing, Service Delivery and Capacities. http://www.clgf.org.uk/default/assets/File/ Publications/ reports/Local Governments in_Southern_Africa_CLGF-UNCDF -UNDP2012.pdf

Constitution of South Africa Act, No. 108 of 1996 (SA). Retrieved from https://www.justice.gov.za/legislation/constitution/SAConstitution-web-eng-0.pdf

Corazzini, A. J. (1967). When should vocational education begin? The Journal of Human Resources, 2(1), 41-50. http://www.jstor.org/stable/144590

Deming, W. E. (1982). Out of the crisis. MIT Press.

Denison, E. F. (1967). Why growth rates differ. The Brookings Institute.

Denzin, N. K., \& Lincoln, Y. S. (2011). Introduction: The discipline and practice of qualitative research. The Sage handbook of qualitative research. Sage.

Department of Co-operative Governance and Traditional Authorities (2009). Local Government Turnaround Strategy Report. Government Printers.

Department of Mineral Resources. (2015). Mining Charter Impact Assessment Report. http://www.dmr.gov.za/publications/.../262-mining-charter-assessment-report-2015.html

Dzansi, L.W., Chipunza, C., \& Monnapula-Mapesela, M. (2016). Municipal Employees' Perceptions of Political Interference in Human Resource Management Practices: Evidence from the Free State Province in South Africa. International Business and Economics Research Journal, 15(1), 15-26. https://doi.org/ 10.19030/iber.v15i1.9572

Fairhurst, D. (2007). Don't lose them, schmooze them. Human Resources, 10(2), 21-35. https://0-search.proquest.com.innopac.wits.ac.za/ docview/228294607?accountid=15083

Field, P. A., \& Morse, J. M. (1985). Qualitative Nursing research: The application of qualitative approaches. Aspen.

Fox, W., \& Meyer, I. H. (1995). Policies for public service transformation. Creda Press.

Gagne, M., \& Deci, E. L. (2005). Self-determination theory and work motivation. Journal of Organizational Behavior, 26(4), 331-362. https://doi.org/10.1002/job.322

Germà, B., \& Gradus, R. (2018). Privatisation, contracting-out and inter-municipal cooperation: new developments in local public service delivery. Local Government Studies, 
44(1), 11-21. https://doi.org/10.1080/ 03003930.2017.1403904

Gilbert, T. F. (1978). Human Competence: Engineering worthy performance. McGraw-Hill.

Gordon, P. A. (2000). The road to success with mentor. Journal of Vascular Nursing, 18(1), 30-33. https://doi.org/10.1016/S1062-0303(00)90059-1.

Guba, E. G. (1981). Criteria for Assessing the Trustworthiness of Naturalistic Inquiries. Educational Communication and Technology, 29(2), 75-91. http://www.jstor.org/stable/30219811 .

Guillermo, P., Burki, S. J., \& Dillinger, W. (1999). Beyond the Center: Decentralizing the State. World Bank.

Harbison, F. H., \& Myers, C. A. (1964). Education, Manpower and Economic Growth: Strategies of Human Resource Development. McGraw-Hill.

Hodder, R. (2009). Political interference in the Philippine civil service. Environment and Planning C Government and Policy, 27(5), 766-782. https://doi.org/10.1068/c0843b

Hoyos, S. C. (2019). Extractive industry revenues and the subnational resource curse: The case of the Peruvian Andes. The Extractive Industries and Society, 6(4), 1134-1142. https://doi .org/10.1016/j.exis. 2019.06 .001

Huang, W., \& Feeney, M. K. (2016). Citizen Participation in Local Government Decision Making: The Role of Manager Motivation. Review of Public Personnel Administration, 36(2), 188-209. https://doi.org/ 10.1177/0734371x15576410

Kickert, W. J. M. (2014). The Specificity of Change Management in Public Organizations: Conditions for Successful Organizational Change in Dutch Ministerial Departments. The American Review of Administrative Science, 44(6), 693-717. https://doi.org/ 10.1177/0275 074013483871

Kotter, J. P. (1996). Leading Change. Harvard Business School Press.

Kwankye, S. O. (2012). Independent North-South Child Migration as a Parental Investment in Northern Ghana. Population, Space and Place, 18(5), 535-550. https://doi.org/:10.10 02/psp. 682

Leshem, S., \& Trafford, V. (2007). Overlooking the conceptual framework. Innovations in Education and Teaching International, 44(1), 93-105. https://doi.org/10.1080/147032906 01081407

Lewin, K. (1947). Frontiers of Group Dynamics: Concept, method and reality in social science, social equilibria, and social change. Human Relations., 1(1), 5-41. https://doi .org/10.1177/0018 72674700100103

Likert, R. (1932). A Technique for the measurement of attitudes. Archives of Psychology, 22(140), 5-55. https://www.researchgate.net/publication/ 200086112_ A_ Technique_for_ Measurement_of_Attitudes. 
Lipton, M. (1977). Why Poor People Stay Poor: Urban Bias in World Development. Harvard University Press.

Local Government Handbook. (2016). Bojanala Platinum District Municipality. http://www.llocalgovernment.co.za/districts/view/9/Bojanala-Platinum-District-Municipality \#map

Local Government: Municipal Structures Act, No. 117 of 1998 (SA). Retrieved from https://www.gov.za/sites/default/files/gcis_document/201409/a117-980.pdf

Local Government Municipal Systems Act, No. 32 of 2000 (SA). Retrieved from https://www.gov.za/sites/default/files/gcis_document/201409/a32-000.pdf

Lohnert, B., \& Steinbrink, M. (2005). Rural and Urban Livelihoods: A Translocal Perspective In A South African Context. South African Geographical Journal, 87(2), 95-103. https: //doi.org/10.1080/03736245.2005.9713832.

Madibeng Local Municipality. (2015). Madibeng Local Municipality IDP Review 2014/15. http://www.madibeng.gov.za/wp-content/ uploads/2015/07/ idpreview_201415.zip

Mayer, P., \& Mayer, I. (1971). Townsmen or Tribesmen. Conservatism and the Process of Urbanisation in a South African City. Oxford University Press.

McAdam, R., \& McCreedy, S. (1999). The Process of Knowledge Management within Organizations: A Critical Assessment of both Theory and Practice. Knowledge and Process Management, $\quad 6(2), \quad$ 101-113. https://doi.org/10.1002/(sici)1099-1441 (199906)6:2<101::aid-kpm53>3.0.co;2-p

Merriam, S. B. (2002). Qualitative research in practice. Jossey-Bass.

Mincer, J. (1974). Schooling, experience and earnings. Colombia University: New York Press.

Mineral and Petroleum Resources Development Act, No. 28 of 2002 (SA). Retrieved from https://www.gov.za/sites/default/files/gcis_document/201409/a28-020.pdf

Morse, J. M. (1991). Approaches to qualitative-quantitative methodological triangulation. Nursing Research, 40(2), 120-123. https://www.ncbi.nlm. nih.gov/ubmed /2003072

Moynihan, D. P. (2010). A workforce of cynics? The effects of contemporary reforms on public service motivation. International Public Management Journal, 13(1), 24-34. https://doi.org/10.1080/10967490903547167

Municipal Finance Management Act, No. 56 of 2003 (SA). https://www.gov.za/sites/default/files/gcis_document/201409/a56-03.pdf

National Treasury. (2011). Local government budgets and expenditure review. Department of Finance

Ndebele, C., \& Lavhelani, P. N. (2017). Local Government and Quality Service Delivery: An Evaluation of Municipal Service Delivery in a Local Municipality in Limpopo Province, 
Journal of Public Administration, 52(2), 340-356. https://hdl.handle.net/10520/EJC -bf4ce318a

Nealer, E. (2014). Local government and service delivery. In Gerrit van der Walt (Ed.), Municipal Management: Serving the people (Chapter 9), 2nd ed. JUTA.

Neuman, L. W. (2011). Social research methods: Qualitative and quantitative approaches. Pearson

Ngwenya, P., \& Botha, P. (2014). The foster care backlog: A threat to the retention of social workers? Social Work, 48(20), 209-224. https://doi.org/10.15270/48-2-99.

Organisation for Economic Co-operation and Development. (2008). The Challenge of Capacity Development: Working Towards Good Practice. Journal on Development, 8(3), 233-276. https://doi.org /10.1787/journal_dev-v8-art40-en

Otto, S., Agapitova, N., \& Behrens, J. (2009). The Capacity Development Results Framework: A strategic and results-oriented approach to learning for capacity development. World Bank.

Rummler, G. A., \& Brache, A. P. (1988). The Systems View of Human Performance. Training, 25(9), 45-53. http://www.performancedesignlabcom/wp-content/ uploads/2012 /04/40.-TheSystems-View-of-Human-Performance1.pdf.

Sana, M., \& Massey, D. S. (2005). Household Composition, Family Migration, and Community Context: Migrant Remittances in Four Countries. Social Science Quarterly, 86(2), 509-528. https://doi.org/10. 1111/j.0038-4941.2005.00315.x

Sanderson, I. (2001). Performance management, evaluation and learning in modern local government, Public Administration, 79(2), 297-313. https://doi.org/10.1111/1467-9299.00257

Schultz, T. W. (1981). Investing in people: The economics of population quality. University of Los Angeles Press.

Serbeh, R., Adjei, P. O., \& Yeboah, T. (2015). Internal Migration and Poverty Reduction: Rethinking the Debate on the North-South Movement in Ghana. Journal of Social Sciences, 12(1), 42-54. https://doi.org/10.3844/jsssp.2015.

Shava, E., \& Maramura, T. C. (2016). A Descriptive Analysis of the Causes, Challenges and Effects of Skills Deficit on Youth Empowerment in South Africa. Journal of Social Sciences, 49(1,2), 93-100. https://doi.org/10.10 80/09718923.2016.11893602

Skills Development Act, No. 98 of 1998. (1998). Government Printers.

Snell, S.A., \& Dean, J.W. (1992). Integrated manufacturing and human response management: A human capital perspective. Academy of Management Journal, 35(3), 467-504. https: //doi. org/10.230 7/256484.

Soukopová, J., \& Vaceková, G. (2018). Internal factors of inter-municipal cooperation: What matters most and why? Local Government Studies, 44(1), 105-126. https://doi.org/10. 1080/0300393 0.2017.1395739 
Stark, O. (1991). The Migration of Labor. Cambridge: Basil Blackwell.

Stark, O., \& Lucas, R. E. B. (1988). Migration, Remittances, and the Family. Economic Development and Cultural Change, 36(3), 465-81. https://econpapers.repec.org /RePEc:ucp: ecdecc:v:36:y:1988:i:3:p:465-81

Statistics South Africa. (2013). Census 2011. Government Printers.

Statistics South Africa. (2016). Community Survey. http://cs2016. statssa.gov.za/

Steinbrink, M. (2010). The Role of Amateur Football in Circular Migration Systems in South Africa. Africa Spectrum, 45(2), 35-60. https://d-nb.info /1024414043/34

Swanson, R. A. (1999). The foundation of performance improvement and implications for practice. Berret-Koehler

Ubels, J., Acquaye-Baddoo, N., \& Fowler, A. (2010). Capacity Development in Practice. London: Earthscan.

Van der Voet, J., Kuipers, B. S., \& Groeneveld, S. (2016). Implementing Change in Public Organizations: The relationship between leadership and affective commitment to change in a public sector context. Public Management Review, 18(6), 842-865. https://doi.org/10. 1080/14719037.2015.1045020

White Paper on Local Government of 1998 (SA). Retrieved from https://www.gov.za/sites/default/files/gcis_document/201409/whitepaper0.pdf

Wolpe, H. (1972). Capitalism and cheap labour power in South Africa: From segregation to apartheid. Economy and Society, 1(4), 425-456. https://doi.org/10.1080/03085147200000023

Zula, K. J., \& Chermack, T. J. (2007). Human Capital Planning: A review of literature and implications for Human Resource Development. Human Resource Development Review, 6(3), 245-262. https: //doi. org/10.1177/1534484307303762

\section{Copyright Disclaimer}

Copyright for this article is retained by the author(s), with first publication rights granted to the journal.

This is an open-access article distributed under the terms and conditions of the Creative Commons Attribution license (http://creativecommons.org/licenses/by/4.0/). 